\title{
DAS ÁGUAS İYÁ OXUM: SABERES ANCESTRAIS FEMININOS EM POESIAS NEGRAS DIASPÓRICAS
}

\author{
Cristian Sales ${ }^{1}$ \\ DOI 10.26512/revistacalundu.v4i2.34575
}

\begin{abstract}
Resumo
Neste artigo, investimos numa discussão acerca dos saberes ancestrais femininos articulados em poesias negras diaspóricas. Dessa maneira, ao apresentar um estudo crítico dos poemas de Lívia Natália e Paula Melissa (Mel Adún), observamos como os arquétipos de İyá Oxum são incorporados como tessituras e fundamentos epistêmicos. A partir de contribuições teóricas formuladas na filosofia africana, o texto explora como o orixá feminino Oxum se torna uma "categoria sócio-espiritual" (Oyěwùmí, 2016) de abertura para uma transformação epistemológica para ver, sentir e compreender o mundo, em contraposição ao pensamento ocidental.
\end{abstract}

Palavras-chave: Poesia negra feminina. Oxum. Saberes ancestrais. Assentamentos de resistência. Epistemologia negra.

\section{DE LAS ÁGUAS ÌYÁ OXUM: CONOCIMIENTO ANCESTRAL FEMENINO EN POESÍA NEGRA DIASPORIANA}

\section{Resumen}

En este artículo, invertimos en una discusión sobre el conocimiento ancestral femenino articulados en la poesía de la diáspora negra. De esta forma, al presentar un estudio crítico de los poemas de Lívia Natália y Paula Melissa (Mel Adún), observamos cómo los arquetipos de İyá Oxum se incorporan como fabricaciones y fundamentos epistémicos. A partir de aportes teóricos formulados en la filosofía africana, el texto explora cómo la orisha Oxum se convierte en una "categoría socioespiritual" (Oyěwùmí, 2016) de apertura a una transformación epistemológica para ver, sentir y comprender el mundo a través de otras fuerzas y lentes en contraposición al pensamiento occidental.

Palabras clave: Poesía femenina negra. Oxum. Conocimiento ancestral. Asentamientos de resistencia. Epistemología negra.

\footnotetext{
${ }^{1}$ Possui graduação em Letras Vernáculas com Espanhol pelo Centro Universitário Jorge Amado (2003). Graduação em Letras com Inglês pelo Centro Universitário Jorge Amado (2005). Especialização em Estudos Linguísticos e Literários pela Universidade Federal da Bahia (2006). É Mestra pelo Programa de Pós-Graduação em Estudo de Linguagens-PPGEL/UNEB (2011). É Doutoranda pelo Programa de PósGraduação em Literatura e Cultura, na linha de pesquisa Estudos de Teorias e Representações Literárias e Culturais, da Universidade Federal Da Bahia (UFBA). Email: crissaliessouza@ gmail.com
} 


\section{Rituais iniciáticos: saudar o Ori}

\section{Ori}

Um rio não caminha só. ele atravessa rasga pedras e fere o chão com sua correnteza translúcida.

A água eu cabe apaziguada no copo.

dança macia nos corpos

e escapa sinuosa das maõs

está sempre caminhando.

Dentro do rio cabe um mais além das margens

[...]

Dentro desta água doce cabe a violência das torrentes.

Dentro da água há um espaço sempre preenchido

onde dança uma mulher castanha e bela.

No fundo, mais que limo e pedra,

Há pulseiras vivas e perfumes feitos de puro mistério.

Quando a água para

-aquietada na carne lívida das lagoas-

dentro dela há muita vida.

Uma luz dourada emana de seus limites

como de um ventre,

enquanto os peixes bebem de seu encanto silencioso.

(SOUZA, 2011, p.29)

Segundo a pesquisadora nigeriana Oyèrónkẹ́ Oyěwùmí (2016, pp.3-4), “Orí significa literalmente cabeça". Orí é elaborado como a sede do destino ou sina individual. "Portanto, destino e sina são dois sinônimos para orí-inú": (cabeça interna) e orí-òde (cabeça externa). Na cosmologia iorubá, "a tarefa mais importante que humanos enfrentam em sua forma pré-terrena é escolher um orí no Orum (outra dimensão do mundo), antes de fazer a viagem para a Terra".

Para Oyěwùmí, talvez o conceito mais importante "na articulação da cosmopercepção ioruba” seja orí. Em face disso, afirma que “[...] Orí é, assim, uma divindade pessoal". É o portador da individualidade de cada ser humano. O Orí atua como um "mediador entre o indivíduo e outros orixás (divindades)". Orí "é uma divindade de pleno direito" em toda a sua força e grandeza que rege nossas existências no Aiyê (OYĚWÙMÍ, 2016, pp. 4-5, grifos da autora). Todavia, para o que aqui interessa, Orí é o único orixá que acompanha seu/sua filho(a) desde o nascimento até a morte.

Em outra compreensão, o pensador nigeriano Wande Abimbola (2011, p. 10,) confirma que Orí está ligado às nossas “aspirações individuais”. Orí é a essência da 
personalidade humana. O Orí é o elemento que "representa o destino humano". Orí é Odu! Nesse aspecto, o Orí [cabeça] é um “deus individual e pessoal” relacionado à prosperidade e destino. Ademais, na visão de mundo dos povos iorubás, o Orí [cabeça] é reconhecido também "como um Òrìsà, tendo seu próprio culto individual" (ABIMBOLA, 2011, p. 10).

Em outro desdobramento filosófico, Muniz Sodré (2017, p. 107, grifos do autor) enfatiza que Orí é reconhecido como "uma divindade pessoal com culto próprio". "À cabeça física (ori) corresponde no plano do orun à cabeça-destino" portadora de axé. Isso significa que Orí oferece a cada indivíduo a possibilidade de "escolha de um destino", de caminho (SODRÉ, 2017, p. 109). "O destino é a escrita da travessia imaginária traçada do orun e aiyê" ${ }^{2}$. O destino aqui é revelado pela adivinhação de Ífá, onde a ancestralidade se assenta e define os Odus ${ }^{3}$. "Um rio não caminha só!" (SOUZA, 2011, p.29).

Para Oyèrónkẹ́ Oyěwùmí, "o conceito de axé é igualmente central para a espiritualidade iorubá e tem sido analisado de diversas maneiras por quem estuda a cultura iorubá". Desse modo, segundo a pensadora africana, o "Axé se traduz como poder, autoridade, comando". No axé estão os recursos místicos, poéticos e os saberes ancestrais femininos (OYĚWÙMÍ, 2016, p.10). Ressaltar os vínculos entre o axé e Oxum é fundamental para uma transformação epistemológica para ver, sentir e compreender o mundo em contraposição ao pensamento ocidental. $\mathrm{O}$ axé, enquanto elemento que substancia a vida em diáspora. $\mathrm{O}$ axé que circula e se assenta nas escritas negras diaspóricas.

Ao mesmo tempo, divindade única e individualizada, devemos saudar, reverenciar, alimentar e cultuar o nosso Orí (cabeça) (OYĚWÙMÍ, 2016, pp. 4-5). Nesse sentido, tal constatação se torna de suma importância, porque a saudação inicial é uma invocação ao Orí da İyá Oxum. Dessa forma, saudamos a İyá Oxum através da

\footnotetext{
${ }^{2}$ Vou utilizar a perspectiva filosófica de Wande Abimbola para explicar a relação entre Orun e Aiyê. Orun e Aiyê não se limitam a céu e terra. Na visão iorubana, no Aiyê, que é também algumas vezes conhecido por isálayé, é o domínio da existência humana, das bruxas, dos animais, pássaros, insetos, rios, montanhas, etc. (ABIMBOLA, 2011, p. 2, grifos do autor). Ainda segundo Abimbola, no Òrun, que é "outras vezes conhecido como isálórun, é o lugar de Olódùmarè ( $\mathrm{O}$ Deus Todo Poderoso), que é também conhecido como Òlórun significando literalmente o proprietário dos céus". Logo, "o òrun é também o domínio dos Òrìsà (divindades), que são reconhecidas como representantes de Olódùmarè; e dos ancestrais" (ABIMBOLA, 2011, p. 2).

${ }^{3}$ Em outra explicação importante assentada na/pela cosmovisão iorubá, "Òrìsànlá (deus da criação) era responsável pela modelagem dos seres humanos, enquanto que Òrúnmilà, também conhecido como Ifá (deus da divinação), foi encarregado com o uso da sabedoria para a interpretação do passado, presente e futuro, assim como também para a "organização geral da terra" (ABIMBOLA, 2011, p.3).
} 
poesia-oferenda a Orí. Ritual de poesia-oferenda à cabeça que traz o equilíbrio necessário aos caminhos (Odu). "[...] Quando a água para /-aquietada na carne lívida das lagoas/-dentro dela há muita vida" (SOUZA, 2011, p. 29).

Da natureza de Orí, neste trabalho, estabelecemos os fundamentos de uma crítica literária em diálogo com aspectos da religiosidade afro-brasileira, evidenciamos como os "saberes ancestrais femininos" estão assentados nos arquétipos de İyá Oxum (MACHADO, 2020, p. 27). A par disso, da palavra grafada aos sentidos das águas com seus elementos significantes (rio, mar, cachoeira, peixe, ventre etc.), a İyá Oxum se torna uma "categoria sócio-espiritual" que aciono para ler e interpretar as poesias de Mel Adún e Lívia Natália (OYĚWÙMÍ, 2016, p.2). Cabe dizer que o significado de İyá está muito ligado "ao poder metafísico inerente que İyá" personificado por Oxum (OYĚWÙMÍ, 2016, p. 29).

De acordo com Adilbênia Freire Machado (2020, p. 30), das águas de İyá Oxum nascem e se fertilizam os "saberes ancestrais femininos". Saberes ancestrais de Abébé Omin que assim são tecidos e in(corpo)rados por "mulheres negras que bordam experiências coletivas, irmanadas, ancestrais e encantadas desde com-partilhas de seus dons, suas vivências, experiências". Mulheres negras que, por meio da palavra-ritual, assentam saberes ancestrais, saberes de terreiro e outros saberes historicamente silenciados ${ }^{4}$.

Diante disso, a filósofa afro-brasileira afirma que "as mulheres negras carregam em si o encantamento das sabedorias ancestrais". Das águas ancestrais! (MACHADO, 2020, p. 30). O encantamento de İyá Oxum: “[...] onde dança uma mulher castanha e bela/ uma luz dourada emana de seus limites/como de um ventre/ enquanto os peixes bebem de seu encanto silencioso" (SOUZA, 2011, p.29). Da mesma maneira que nada se faz sem a autorização de Orí, são as nossas mais velhas que nos ensinam a abrir os caminhos louvando o Orí (cabeça). Aportando-se à definição, em uma dimensão ritualística, Ori é potência da vida! Força ancestral que irradia e extravasa. É poder do transe litúrgico em palavra ${ }^{5}$. Àgò! Osun Ora yèyé Ó!

\footnotetext{
${ }^{4}$ Penso que esses saberes ancestrais e saberes de terreiro circulam e se assentam na crítica, teoria e ficção: poesias, romances, ensaios, contos.

${ }^{5}$ Como tomo a palavra? Por que palavra-transe? "No rito-nagô, a palavra é, assim, mais performativa do que semântico-referencial". Ou seja, "a palavra aqui não é puro signo linguístico com um significado". Numa dinâmica regida de axé e ancestralidade, "a palavra em nagô implica a unicidade corporal de uma presença indissociável de seus gestos, dons e tons" com suas forças visíveis e invisíveis. É incorporada de sentido. Como "o axé se transmite através do contato, da comunicação, do hálito, da fala e da interação ritual". O axé está inscrito na palavra. A ancestralidade negro-africana está assentada na palavra/na poesia de mulheres negras. O axé se assenta na palavra. Palavra-transe. (SODRÉ, 2017, pp. 138-139).
} 


\section{De Abébé Omin: saberes ancestrais femininos}

"O leito do rio, quase seco, sussurra que já foi correnteza".

(Mel Adún, 2014, p. 149)

Primeiramente, é preciso apresentar por que é tão importante entender a questão da ancestralidade ? Revela-se assim a importância dos itans, no Candomblé e na resistência diaspórica negra, uma resistência na transmissão oral. De acordo com Eduardo Oliveira (2007, p. 128), a ancestralidade era uma categoria explicativa ligada ao fazer/ existir do povo de santo, "considerada o princípio fundamental de organização dos cultos de candomblé". Em seguida, torna-se "um termo em disputa [...] nos movimentos negros organizados, nas religiões de matriz africana, na academia e até mesmo nas políticas de governo" (OLIVEIRA, 2007, p. 141). Nesse sentido, "a ancestralidade é um território sobre o qual se dão as trocas de experiências: signicas, materiais, linguísticas" (OLIVEIRA, 2007, p. 141).

A partir desses pressupostos, Oliveira orienta que a ancestralidade nos permite compreender a experiência e resistência negro-africana no Brasil. A ancestralidade se converte em uma referência e fundamento da resistência de nossos antepassados. Em linhas gerais, "a ancestralidade torna-se o signo da resistência afrodescendente" nas escritas de mulheres negras diaspóricas (OLIVEIRA, 2007, p.3). É a palavra numa "dinâmica regida pelo axê" em uma apreensão rítmica em "variadas modulações da existência" (SODRÉ, 2017, p. 140, grifos do autor).

Diante disso, para falar de resistência, é necessário pensar em cosmovisões, formas de ser e estar no mundo, marcas, memórias, as quais são assentadas nas poesias de Lívia Natália e Mel Adún. No assentamento de uma percepção do prolongamento da existência, dos ritos, dos valores, dos princípios, das práticas mítico-religiosas trazidas e reinventadas na diáspora ${ }^{6}$. A potência de realização em que consiste o axé de İyá Oxum (SODRÉ, 2017, p. 151, grifos do autor).

Por essa ótica, a ancestralidade negro-africana nos possibilita reconectar à memória do corpo que, embora eivada de uma saudade da origem, torna-se território de

\footnotetext{
${ }^{6} \mathrm{Em}$ minha tese de doutorado intitulada Assentamentos de resistência: intelectuais negras do Brasil e Caribe em insurgências epistêmicas (2020), busco tornar operatório o conceito de assentamento para ler, interpretar e traduzir a produção epistêmica e de conhecimento de mulheres negras em diáspora. Os assentamentos de resistência estão fortemente ligados à ancestralidade negro-africana e às histórias e aos legados de resistência de las ancestras. Dessa forma, manifestam-se através dos saberes de ancestrais, saberes de terreiros e saberes ancestrais femininos através das poesias, romances, contos e ensaios críticos de autoria negra.
} 
tanto de ressemantização quanto de continuidade dessa lembrança que tem no passado a garantia de sua continuidade. Desse modo, é necessário se perceber dentro do próprio fluxo de continuidade dessa linhagem negra e que a "[...] travessia nos 'negreiros' nunca foi uma viagem solitária” (OLIVEIRA, 2007, p. 103, grifos do autor).

Por outro lado, "a ancestralidade é uma categoria de relação, ligação, inclusão, diversidade, unidade e encantamento" (OLIVEIRA, 2007, p. 145). Nesse caso, o filósofo enfatiza que encantamento é uma das funções da ancestralidade. "O encantamento é uma palavra "mágica e potente". Encantar é a finalidade da ancestralidade" (OLIVEIRA, 2007, p. 146). Encantar e "reencantar" tornam-se caminhos de poesia para İyá Oxum (GARUBA, 2002). Caminhos trilhados por mulheres negras em diáspora.

Desta maneira, podemos perceber como as referências e definições, em Oliveira e Sodré, ajudam-nos a sentir a potência de İyá Oxum nas palavras de Paula Melissa (Mel Adún): [...] "o leito do rio, quase seco, sussurra que já foi correnteza”. Nestas liturgias rituais, enquanto segue com seus mistérios, as palavras de encantamento e reencantamento são dirigidas a orixá das águas doces (OLIVEIRA, 2007, p. 146).

Sendo espaço de expressão do sagrado, sobre a escrita, Machado nos orienta que os textos de Mel Adún e Lívia Natália são saberes tecidos, fundamentalmente, "por mulheres negras que bordam suas experiências coletivas, irmanadas, ancestrais e encantadas" (MACHADO, 2020, p.30). Nesse caso, suas escritas poéticas se transformam nas tessituras ancestrais que assentam saberes trazidos/herdados por nossas mais velhas. Saberes ancestrais e saberes de terreiro que podemos chamar de assentamentos de resistência.

Ainda em menção ao texto de Oliveira, o olhar encantado da poeta negra diaspórica constrói "um mundo encantado" (OLIVEIRA, 2007a, p. 146). "No território do encantamento cabe tudo: o visível, o invisível", o que sussurra e, ao mesmo tempo, torna-se correnteza. Sem dúvida, nesse encantar e reencantar o mundo através da palavra-sussurro, Mel Adún faz referência ao orixá feminino Oxum. Nesse caminho, entre transe e muitos trânsitos, a ancestralidade negro-africana, por assim dizer, manifesta-se através do espírito de intimidade com a natureza (OLIVEIRA, 2007, p. 149).

Para além da racionalidade ocidental, que privilegia o sentido da visão como símbolo da inteligência, compreendendo como apartado de corpo e materialidade dos sentidos, ao escutar a episteme mesmo se revela com o som de águas dos rios, revela-se, 
então, essa ligação com a natureza e ao que os orixás nos convidam a sentir o mundo, o cosmos, em outra dimensão:

[...] É preciso sentir. É preciso aprender a lidar com o mundo de uma outra maneira que não aquela que nos circunda habitualmente. É preciso re-ver o mundo de ponta cabeça. Precisa-se desconstruir o corpo que se tem e o corpo das representações que carregamos. É preciso re-ver a cultura que lhe tece a pele; necessário mergulhar naquilo que lhe é mais seu e despojar-se disso como uma serpente que troca de pele, ou como a ave que troca de penas. Doravante viver sem pele ou plumas. Ou melhor, viver com muitas. (OLIVEIRA, 2007, p. $103)$.

Nota-se, também, que a questão abordada, partindo das poesias de Mel Adún e

Lívia Natália, tem uma forma de escrita para reverenciar Oxum, a presença da ancestralidade que carrega muitos orís (cabeças). São poesias que brotam da terra, avançam o céu, penetram nas profundezas dos rios, cachoeiras e marés. Inauguram um ciclo de palavras úmidas e únicas.

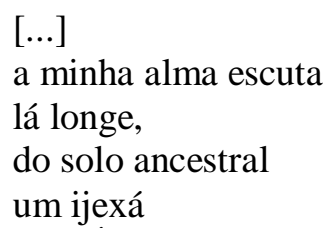

Ao toque do ijexá, os "retratos conceituais" se tecem e são encomendados como epistemologias (OYĚWÙMÍ, 2016, p.6). São saberes “carregados de histórias, de filosofias e sentidos". Logo, os versos colaboram para o "fortalecimento da nossa existência, que permite a resistência, a re-existência" e se assenta como uma práxis negra (MACHADO, 2020, p. 32). A arte fornece "a metáfora visual" que carrega uma mensagem ancestral de nossas mais velhas. Em todo o caso, é importante ressaltar que os processos poéticos e criativos se banham e se fortalecem nos rios, lagos e em fontes de águas doces:

\section{Omin}

Sou enchente

Das águas profundas,

Escuras

Poço sem fundo

Fatal para os desavisados

Farta para os que com cuidado 
Se agacham para pedir: "sua benção, minha mãe!"

Ora rio Yê yê o, rio Ora yê yê ô, yalodê

Sou por vezes maré vazante

Com vontade de tirar tudo de dentro.

Os desatentos pensam que vou secar...

Mas é só o sol descer

Que volto a encher

Enchente, profunda, escura

Fatal e farta

Sou água.

(ADÚN, 2008, p. 91, grifos meus).

\section{Oxum Oyê}

“Oxum é a İyá, a Fonte da vida” (OYĚWÙMÍ, 2016, p.22). Por esse motivo, a İyá fundamenta um dos saberes ancestrais femininos que "têm um axé [àsẹe] especial (poder da palavra)" (OYĚWÙMÍ, 2016, p.10, grifos da autora). De forma singular, Oxum é uma "categoria sócio-espiritual" de abertura para "uma mudança epistemológica de uma cosmopercepção" (OYĚWÙMÍ, 2016, p.2). Na produção de conhecimento, mobilizamos os poderes e os valores espirituais da İyá Oxum.

Ao apontar a centralidade em Oxum, Oyěwùmí chama atenção para todos os esforços espirituais dessa Ìyá. Oxum é a "İyá primordial” (OYĚWÙMÍ, 2016, p.23)7 . Oxum é a nossa "İyá soberana" (OYĚWÙMÍ, 2016, p.29). Com o título de Ialodê, "ocupa a única posição aberta para fềmeas no sistema político de Ibadan"8 (OYĚWÙMÍ, 2016, p.32). Oxum domina os espaços públicos, sendo uma grande referência ao povo, aglomerações, espaços coletivos, como multidões etc. Ela é a "İyá do povo, İyá da humanidade" (OYĚWÙMÍ, 2016, p.33).

Vale ressaltar que Oxum, a İyá primordial, é reconhecida como tendo três profissões: divinadora, cabeleireira e vendedora de alimentos (OYĚWÙMÍ, 2016, p.24). De acordo com Oyěwùmí, as İyá iorubás “valorizam sua autonomia e acreditam que é o cúmulo do insulto para uma fêmea adulta ter que pedir a alguém dinheiro para comprar coisas como sal e variedades; seria um desrespeito" (OYĚWÙMÍ, 2016, p.24).

Dito de outra maneira, Oxum é uma divindade iorubana que representa a beleza, a feminilidade, a fertilidade, o amor, a maternidade, a insubmissão feminina, dentre

\footnotetext{
${ }^{7}$ De acordo com İyá Oyěwùmí (2016, pp.-23-24), os iorubás são conhecides por sua produção e trabalho em prol de sua progenitura. A base do seu engajamento ocupacional é prover seus filhos. "[...] As İyá iorubás valorizam sua autonomia e acreditam no seu poder fêmea. A preocupação de İyá era defender sua prole" (Oyěwùmí, 2016, p.26).

${ }^{8}$ Em Ibadan do século XIX, a criação de um título de chefia apenas de mulheres assinalou a emergente consciência de gênero em um estado militarista.
} 
outros atributos o poder feminino em suma. Sua casa são as águas, como mostra Oxum que "habita as águas doces, condição indispensável para a fertilidade da terra e produção de seus frutos, donde decorre sua profunda ligação", por exemplo, com "a gestação" (CARNEIRO e CURY, 1993, p. 23).

Oxum significando o poder feminino, também rende homenagem à cor amarela que espelha riqueza, como Oxum que "é o amarelo-ouro, e gosta de adornos dourados. Quando dança, espalha o ouro e espelha-se no seu abébé”, sendo seus movimentos muito exultantes (CARNEIRO e CURY, 1993, p. 24, grifos das autoras). Desse modo, trazendo o culto dos orixás para o contexto brasileiro do Candomblé, Sueli Carneiro e Cristiane Cury (2008, p. 102) afirmam que o Candomblé "nasce como um campo possível de resistência e sobrevivência cultural”.

No Brasil, o Candomblé se constituiu originalmente numa comunidade eminentemente feminina. "O passado de luta, a determinação e a resistência da mulher negra marcam profundamente o povo de santo" (CARNEIRO \& CURY, 2008, p.123). As yalorixás "são as grandes depositárias e transmissoras dos conhecimentos ancestrais herdados: seus mistérios e segredos, de sua magia". (CARNEIRO \& CURY, 2008, p.124).

Carla Akotirene (2019, fonte eletrônica) aprofunda na resistência ao epistemicidio que se vive no Brasil, ao afirmar que Oxum "faz parte da resistência dos escravizados trazidos pelas águas, das conexões religiosas e da espiritualidade cumpridoras da missão de fazermo-nos viver belas, autônomas". Nessa perspectiva, a pensadora negra defende que somos "[...] fortes suficientemente para carregar o ouro não somente por causa do brilho". Por isso, estamos longe das "estereotipias da dondoca, frágil, superficial" 9 .

Mais significativamente, Akotirene assevera que "a construção de poder materno, por exemplo, remete a Osun" 10 . "Osun vive na oralidade e na escrita dispostas a traduzirem a beleza das mulheres negras, a sabedoria, a inteligência, a habilidade na administração das riquezas e dentro das ciências sociais". Oxum está distante "da imagem da mãe chorona, parideira, contrária aos direitos sexuais e reprodutivos das mulheres" (AKOTIRENE, 2019, fonte eletrônica).

\footnotetext{
9 Disponível em https://www.cartacapital.com.br/opiniao/osun-e-fundamento-epistemologico-umdialogo-com-oyeronke-oyewumi/acesso em 03 de outubro de 2020.

${ }^{10}$ A grafia aqui se modifica de Oxum para Osun, porque respeita o pensamento de Carla Akotirene. Mas, em todo o trabalho, preferimos grafar Oxum como aparece no texto traduzido de Oyèrónkẹ Oyěwùmí (2016).
} 
Nas palavras de Eduardo Oliveira (2007, p. 60), "a história dos ancestrais africanos permanece inscrita" e escrita nos "corpos dos afrodescendentes". Por isso, é preciso ler o texto do corpo e no corpo do texto para vislumbrar "a cosmovisão que dá sentido à história dos africanos e afrodescendentes espalhados no planeta". Segundo o autor, a "ancestralidade é um modo de interpretar, produzir a realidade" (OLIVEIRA, 2007, p. 145).

Nesse universo mítico-simbólico, os textos de Lívia Natália e Paula Melissa (Mel Adún) se convertem num território de assentamento de saberes ancestrais femininos que circulam desde os terreiros de candomblé ${ }^{11}$. Por outras lentes, Carla Akoritene (2019) reflete que esses conhecimentos são utilizados como referência e fundamento epistêmico na elaboração de tessituras poéticas: de "[...] dentro da água há um espaço sempre preenchido / onde dança uma mulher castanha e bela" (SOUZA, 2011, p.29).

Ao enfocar nas poesias negras diaspóricas, o assentamento, portanto, relacionase intimamente com a ancestralidade negro-africana e os saberes ancestrais femininos. Assentar tem relação com a nossa resistência diaspórica. Os assentamentos são canais diretos com os orixás e os ancestrais. É energia que circula e, ao mesmo tempo, simultaneamente, força que pode ser fixada através da palavra-ritual para reverenciar Oxum. Ao estabelecer os primeiros rituais e fundamentos epistêmicos, os poemas de Lívia Natália e Paula Melissa (Mel Adún) assentam a possibilidade de uma leitura de mundo a partir da matriz africana. Em larga medida, as vozes poéticas encadeiam e desencadeiam uma rede de significações que nos conecta a uma memória ancestral em diáspora $^{12}$.

\section{Agó, Omi mimọ!}

“Escrever é, ao mesmo tempo, abébé e agadá”. (ADÚN, 2014, p. 167)

\footnotetext{
${ }^{11} \mathrm{O}$ assentamento possui uma relevância importante, uma vez que está ligado ao assentamento de orixá. "O orixá individual é fixado numa pedra - o otá - que é guardada ao interior de um pote ou vasilha (ibá), de louça ou barro, a depender do orixá” (RABELO, 2011, p. 23).

12 Diáspora se baseia na etimologia muito citada do termo do grego dia que significa "através" e speirein que significa "semear" ou "Dispersão". O termo é encontrado no livro do Deuteronômio 28: 25. Em outra perspectiva, os primeiros usos do conceito diáspora africana e atlântica estão ligados aos chamados Estudos Africanos surgidos também na década de 1960. Para além do sentido religioso, representa êxodo, expatriação, deslocamentos e migração não voluntária Já, nos termos de Stuart Hall (2003), o termo diáspora tem designado a dispersão forçada do povo africano pelo mundo atlântico.
} 
Na mitologia yorubá, Oxum é um orixá feminino que "habita as águas doces, condição indispensável para a fertilidade da terra e produção de seus frutos, donde decorre sua profunda ligação", por exemplo, com "a gestação"13 (CARNEIRO e CURY, 1993, p. 23). Entre os símbolos rituais dessa divindade feminina está o abébé que simboliza a sua relação com a beleza, a faceirice, qualidade que são próprias das filhas de Oxum.

Tal fato é particularmente interessante em outro ìtàn, produzido por uma cultura oral que canta e dança com o corpo, experimenta o transe e da sua multiplicidade no recontar. Perante isso, vemos, pois, que Oxum morava perto da lagoa, perto de ossá. Todos os dias, Oxum se dirigia à lagoa e se banhava ${ }^{14}$. Lá, ela polia suas pulseiras, seus indés.

Cotidianamente, Oxum, muito vaidosa e cuidadosa com a sua beleza, caminhava junto às margens, sobre as pedras brutas para alisar seus pés. Oxum ia à lagoa "brunir os seus indés, e, na lagoa, lavava seu punhal, seu idá"15. Banhava o corpo arredondado, lavava seus cabelos, lixava seus pés nas rochas ásperas de ossá. "Dentro da lagoa, Oxum dançava suas danças e cuidava de suas ferramentas. [...] Quando as águas estavam altas na lagoa, Oxum, o peixe, nadava para as bordas da ossá” (PRANDI, 2011, p. 317).

Abébé é uma expressão yorubá que significa espelho de água. É um espelholeque de forma circular que simboliza Oxum (quando de latão e tendo uma estrela no centro, batida ou vazada). O Abébé Omin integra um vasto campo lexical fecundado na aquosa negrura de arquetípicos, orikis e saudações que desaguam um rio de palavras para a mãe das águas doces. "No espelho-leque, vejo refletido um ato de comunicação que adquire valor político-artístico, estético-político e conduz às nossas práticas sociais no interior das comunidades onde, nós, mulheres negras estamos inseridas" (SALES, 2018, p. 34).

É interessante notar que Oxum, “a İyá primordial, como nos diz o odu Oseetura, é honrada pelas pessoas que lhe são devotas não apenas porque ela lhes dá a prole, mas também porque a divindade as provê" (OYĚWÙMÍ, 2016, p.23). Esses sentimentos são

\footnotetext{
${ }^{13}$ Extraídos do livro Mulher Negra, edição comemorativa, organizada pelo Geledés Instituto da Mulher Negra, publicado originalmente em 1993. A série Cadernos Geledés consiste em um conjunto de publicações resultado da ação política do Geledés - Instituto da Mulher Negra. Nele, refiro-me ao artigo intitulado $O$ Poder Feminino no Culto aos Orixás.

14 A palavra itan (nome singular e plural) é o termo de origem iorubá utilizado para representar um conjunto de todos os mitos, canções, histórias e outros. Os itan são transmitidos oralmente de geração a geração.

${ }^{15}$ Ver em Prandi, Reginaldo. Mitologia dos orixás. São Paulo: Companhia das Letras, 2001, p. 318-345.
} 
repetidos continuamente nos orikis de Oxum e nas canções dedicadas à divindade. Em termos espirituais, a divindade Oxum preside o grupo de İyàmi ou àwọn Ìyá, uma "sociedade secreta de mulheres poderosas cujo poder, pensa-se, deriva do papel procriador" (OYĚWÙMÍ, 2016, p.34).

Assim, podemos considerar que Oxum é o símbolo da Matripotência em que se assentam "os poderes, espiritual e material, derivados do papel procriador de İyá". Oxum é o "ethos matripotente expressa o sistema de senioridade em que İyá é a sênior venerada em relação a suas crias". Nesse caso, como fillhas de Oxum, Lívia e Mel Adún cumprem esse ritual. Segundo Oyěwùmí, como todos os humanos têm uma İyá, todos nascemos de uma İyá, ninguém é maior, mais antigo ou mais velho que İyá (OYĚWÙMÍ, 2016, p.3).

Em outro itan, após desafiar o Rei Orixalá, denunciando as injustiças contra todas as mulheres, "os brados de Osun com as suas maldições causaram um grande alarido, uma confusa tamanha". "Foi vencendo essas demandas que Oxum se tornou a dona de todo ouro e de toda riqueza" (EVARISTO, 2013, fonte eletrônica). Deste modo, Oxum protege todas as mulheres negras insubmissas e insurgentes. Águas doces bem(dizem) nossas poesias e saberes.

\footnotetext{
Abebé Omin

Dança bruta e verdadeira no chão de minha alma, prepara meu corpo para ser sua morada: vomito quizilas e fico de novo límpida e casta. Lava meus pés com seus cabelos de água, lava meu ventre, minhas mãos...

Se põe inteira ante mim na proporção exata e necessária, preenchendo tudo com seu castanho cristalino. A mim tudo deu e tudo dará, e entrego dourada e rubra minha cabeça a teus pés, para que aqui caminhe, habite, deite e viva, agora e sempre, dentro desta lagoa funda e branda, neste rio que corre de mim a mim. (SOUZA, 2011, p. 35)
} 


\section{Sobre as autoras}

\section{Lívia Natália}

Nascida em 25 de dezembro de 1979, baiana de Salvador, Lívia Natália ou Lívia Natália Maria de Souza Santos, Omo òrìsà de Òsun e de Odé ${ }^{16}$, de fundamento Ketu, além de ser poeta, possui mestrado (2005) e doutorado (2008) em Teorias e Crítica da Literatura e da Cultura, pela Universidade Federal da Bahia, onde também é professora adjunta de teoria literária (2010).

Para as mulheres negras, a relação com os orixás e os ancestrais está inscrita no Odu (destino). Refiro-me à espiritualidade nosso ser e existir. Lívia Natália narra que suas conexões com os Orixás eram profundas, pois, "desde a mais tenra idade", incorpora de Oxum. Mas, somente aos trinta anos, a escritora, finalmente, foi consagrada ao Orixá, transformando suas percepções: "eixo do meu mundo se alterou por completo" (SOUZA, 2018, p. 195). Esse evento permitiu re-existir e renascer.

Carrego comigo uma Djina, um Orunkò, um nome que me plantou dentro de mim e este nome me diz que sou parte da coroa que adorna e empodera a bela cabeça de Osun, minha Mãe. (SOUZA, 2018, p. 195). E este mesmo nome me promete a alegria. Como sabemos, o nome do nosso Orixá é um segredo de vida, portanto, revelo apenas o que este orunkò significa: "coroação da alegria" (SOUZA, 2018, p. 195, grifos da autora).

Nas antologias Água Negra e Correntezas e outros estudos marinhos, os versos são feitos com muita doçura, elegância na proporção exata e necessária: [...] "Sou a Água eternamente translúcida. Precipício denso de onde estes peixes bebem... um silêncio delicado", afirma a voz literária (SOUZA, 2015, p.31). Poemas feitos em transe...! "Dança violenta e bela na crista de minha alma. Uma voz de água doce sussurra" (SOUZA, 2011, p. 35).

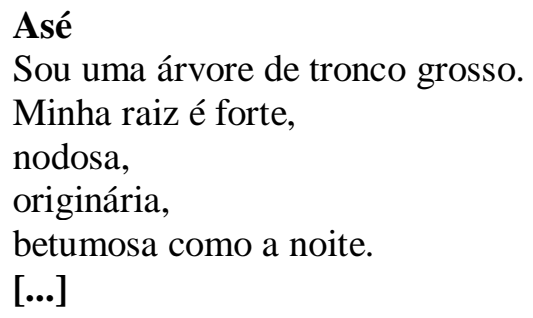

\footnotetext{
${ }^{16}$ Lívia Natália é uma das Egbomes do Ilê Axé Opô Aganjú, já tendo feito a sua obrigação de sete anos (odu ejé). Segundo Mãe Stella de Oxossi, egbon "é o mais velho, mais maduro" (SANTOS, 2010, p. 172). Ver o livro Meu tempo é agora.
} 


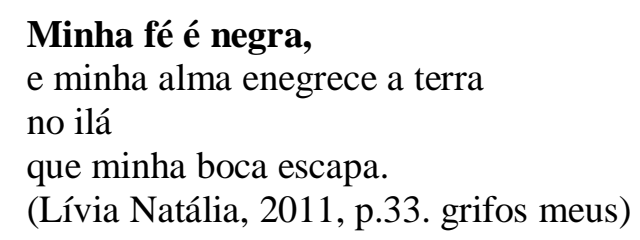

Lívia Natália com sua poesia traz uma fala, que aqui estrategicamente posicionada reafirma que as poesias negras diaspóricas se tornam territórios de assentamento da produção epistêmica negra, como quando ela afirma (2018, p. 198): "para nós, representar Orixás e outros seres encantados constitui uma política de representação, não um artifício literário que constitui um universo representacional fantástico".

\section{Mel Adún}

Filha de Oxum, jornalista, fotógrafa, tradutora, contista e poeta, Mel Adún é o pseudônimo da intelectual negra diaspórica Paula Melissa Alves. Nascida em Washington D.C, nos Estados Unidos, em 1978, em razão do exílio dos pais que fugiam da ditadura militar, veio para o Brasil ainda criança em 1984. Em 1998, já adulta, regressa aos EUA para estudar, retornando ao Brasil em 2001, quando se naturaliza brasileira, fixando residência em Salvador (BA).

Percorrendo outros meandros de sua trajetória, Mel Adún participou de várias edições dos Cadernos Negros e faz parte do Coletivo Literário Ogum’s Toques Negros. É idealizadora do web TV Tobossis Virando a Mesa, um programa que aborda questões relacionadas ao gênero e à raça. Foi uma das diretoras do Didá Associação Cultural Educativa de Mulheres fundada sem fins lucrativos em 1993. Ativista do Movimento Negro e feminista negra, "acredita que a militância como uma forma de ser, visível na postura, na escrita, no jeito de vestir, de agir e de discursar" (ADÚN, 2016, p. 69).

Quanto à tematização dos saberes ancestrais, revelando os muitos mistérios que nos envolvem, Mel Adún compartilha: “[...] venho de uma família de Candomblé da Bahia e eu não teria como me desvincular disso ou me separar do meu ativismo mesmo se quiser" (ADÚN, 2016, p. 70). Nesse sentido, a escritora negra reconhece que não teve escolha. A ancestralidade nos ensina e nos prepara aberturas. É questão de caminho (Odu)!

De abébé nas mãos, Mel Adún (2011, p. 10) acredita que "toda vez uma mulher negra fala por si mesma em uma obra" é um gesto de empoderamento de outras mulheres. É uma escrita negra feminina que traz consigo e compartilha a experiência da 
coletividade feita na comunhão de nossos afetos, crenças, memórias e histórias individuais, assim de nossas "dores dolorosas" que cicatrizam no molhado. Essa escrita que dá "voz a milhares de outras mulheres, negras ou não". Nos versos, o eu poético funde-se e confunde-se:

\author{
Aguada \\ Minhas dores dolorosas morrem comigo. \\ Sou das águas e a cicatrização no molhado é mais difícil. \\ Por isso vide bula. \\ Nesse caso é melhor não agitar antes de usar.
}

(ADÚN, 2011, p.151)

Guiada pelas águas de seu Ori, Mel Adún costuma afirmar que "a sua escrita é negra porque vem de uma realidade negra" (ADÚN, 2016, p. 69). "Eu escrevo poesia que tem muito a ver com a realidade da mulher negra" (ADÚN, 2016, p. 72). Por isso, a intelectual negra transfigura poeticamente suas experiências enquanto mulher negra em diáspora. A escrita abébé "das águas profundas e escuras" que pede a benção e faz a saudação a Omin: “[...] Ora rio Yê yê o, rio Ora yê yê ô, yalodê"” (ADÚN, 2008, p. 91).

Dessa maneira, as águas se tornam um significante ancestral que integra as poesias de Mel Adún. "É a espiritualidade entranhada em nosso viver/ser" (MACHADO, 2020, p. 33). As águas como símbolos do feminino, da vida, da maternidade e da fertilidade, reencenam na poesia Irê!: “[...] Nas águas de Oxum / sou peixe de barriga cheia/ atingida pela flecha certeira/ Trago no ventre o poder de gerar, explodirei água explodirei /sorte Ominirê" (ADÚN, 2012, fonte eletrônica). “O poder procriar é considerado um presente, um dom espiritual" (OYĚWÙMÍ, 2016, p.47).

Sob outra forma, a filosofia africana, portanto, territorializa a expressão sensível na poesia de Mel Adún que anuncia outros significantes importantes de revelação nos saberes femininos diaspóricos, presentes em Oxum e no Candomblé, assentados também na resistência da poesia negra. Os princípios cosmológicos, ancestrais e a dinâmica ritualística. "O transe mítico" (SODRÉ, 2017, pp. 122-123). Podemos dar alguns exemplos como o prolongamento entre o que é visível e o que é invisível, as simbologias no plano de uma espiritualidade, como também fundamentos epistêmicos que são princípios coletivos de bem viver juntos, ou seja, princípios de uma ética, de um caráter.

Estes fundamentos epistêmicos podem ser reconhecidos na conexão míticoreligiosa e ancestral que se estabelece através da identificação com os arquétipos do 
orixá feminino Oxum: o peixe símbolo da vida, da fecundidade, sedutora, fatal e acolhedora. "Enchente, profunda, escura /Fatal e farta / Sou água" (ADÚN, 2008, p. 91). Na escrita feminina negra diaspórica "vigora a atmosfera da ancestralidade" (SODRÉ, 2017, p. 115).

Ao tomar "águas de Oxum" como símbolo da vida, maternidade e fertilidade, através da voz poética, Mel assenta "nossos saberes, nossos valores, nossos sentidos" (MACHADO, 2020, p. 31). Saberes epistêmicos, princípios, sentidos tecidos pela ancestralidade negro-africana que permitem o "fortalecimento da nossa existência" (MACHADO, 2020, p.32). Sem ser exaustivo, de acordo com Machado, a "força das mulheres africanas, das mulheres negras, perpassa o tempo e o espaço, uma força presente no cotidiano, no nosso falar, dançar, cantar, ouvir, fazer, em nosso paladar, nas religiões de matriz africana, no nosso modo de acolher, de ser" (MACHADO, 2020, p.42).

Segundo Machado, "a natureza é a ancestralidade em nós, o feminino criando, possibilitando a vida" (MACHADO, 2020, p. 40). Oxum representa a natureza e os saberes ancestrais femininos. Oxum é, portanto, a nossa "yalodê" (mais importante das mulheres, em iorubá) que controla as marés, os refluxos e influxos dos rios do mundo, mas, especialmente, no estado de Oshogbo:

Vou-me embora pra Oshogbo
Lá sou filha de rainha
Me deitarei só com quem eu quiser
Só se for vontade minha
Vou-me embora pra Oshogbo
Vou-me embora pra Oshogbo
lá vou ser feliz
não terei que me relacionar
com homens de qualquer lugar
espanha, estados unidos, paris
Só se for vontade minha
[...]
(ADÙN, 2014, p. 154, grifos meus)

Oshogbo é a capital do estado de Òşún da Nigéria e localiza-se entre Ibòkun, Ikirun, Ede e Akodá. Em Oshogbo, acontece, anualmente, um Festival de Oxum (Festival sagrado de Oxum) onde são feitas oferendas para reverenciar essa Rainha ${ }^{17}$. Como representa a beleza e a riqueza, as celebrações são sempre com danças, presentes,

\footnotetext{
${ }^{17}$ Mel Adún dialoga de maneira intertextual com a poesia Vou-me Embora pra Pasárgada do poeta modernista Manuel Bandeira.
} 
joias e flores etc. No Brasil, em ritmo de ijexá, as festas para Oxum também se destacam pela devoção e rituais.

De forma amorosa, é um momento de renovação e fortalecimento com os laços ancestrais através da reconexão com a divindade das águas doces. Segundo Carla Akoritene, em Osogbo e nas demais cidades, "Osun encontra-se cultuada como guerreira diplomática". Desse modo, instala-se "a soberania iyalódè alimenta com água o mundo nos seus fluxos de conhecimentos" (AKOTIRENE, 2019, fonte eletrônica).

Associado a isso, a voz poética lembra que Oxum é uma orixá que defende distintas pautas relacionadas ao feminino. Em Vou-me embora pra Oshogbo, o sujeito lírico explora questões afetivas, relações de gênero, emancipação e empoderamento coletivo. Lembrando muitos orikis e itan que aprendi, a poeta negra diaspórica enfatiza que Oxum se torna uma das porta-vozes contra o patriarcado, o sexismo e a dominação masculina etc.

\section{Lá sou filha de rainha \\ Me deitarei só com quem eu quiser \\ Só se for vontade minha \\ [...] \\ lá vou ser feliz \\ não terei que me relacionar \\ com homens de qualquer lugar \\ espanha, estados unidos, paris}

Só se for vontade minha

(ADÙN, 2014, p. 154, grifos meus)

Em Vou-me embora pra Oshogbo, o sujeito poético celebra a sua liberdade de escolha para sentir e amar. Oxum representa o poder feminino através do arquétipo das mulheres insubmissas e corajosas: donas de seu corpo, de seu desejo, de suas vontades. Das terras de Ijexá, Oxum transborda suas forças espirituais. Águas de um Rio que se expandem e tomam muitos contornos, que se transformam, confundem-se e ampliam-se, desaguando em insurgências negras epistêmicas. As águas aparentemente calmas que se levantam sinuosas: um dia em passos miúdos, outros insubmissos.

Em represália aos homens, logo que o mundo foi criado, Oxum vingou-se dos orixás masculinos, obrigando-os a buscar ajuda com Olodumare. Quando Olodumare soube que Oxum havia sido excluída das reuniões, da divisão dos cargos e da tomada de decisões, aconselhou os orixás a convidá-la, e às outras mulheres. Como Oxum não se conforma com a situação, condenou todas as mulheres à esterilidade. Dessa forma, assim que pode participar do processo decisório e ser ouvida, Oxum com seu poder de fecundidade permitiu que as mulheres voltassem a gerar filhos. 
Para Machado, "o feminino está em tudo, em todos os lugares, ele é a possibilidade de criar, de nascer, é escuta, sensibilidade, motor da existência, inclusive, do próprio mundo" regido por Oxum. "O feminino é a energia do encantamento" em Oshogbo e na diáspora. O feminino negro das Águas İyá Oxum "é o que dá vida, permite a vida...". "Implicação, resistência, cuidado, encanto" (MACHADO, 2020, p. 44).

De maneira mais significativa, esses sentimentos e sentidos são repetidos continuamente nos orikis, itan de Oxum. Regida por essa força mítico-ritual, com passos miúdos e certeiros, o feminino negro dourado que dança e marca graciosamente o significado de cada verso ao ritmo do ijexá, pois sabe o que espera evocar em sua poesia:

\title{
ORISA DIDÊ
}

Arranca as percatas de seu cavalo e nele galopa com os pés no chão.

Solta um grito que se espeta no alto

e, repetido, saúda a terra com a majestade de sua presença.

Dança sem a calma das horas, pois seus braços se erguem para fora do tempo.

Caminha com sua carne de mito e, quando vai, não parte.

Apenas se banha em seu próprio mistério. (SOUZA, 2015, p. 41)

$\mathrm{Na}$ escrita negra diaspórica, Oxum é poder e autoridade das fêmeas. Nelas, as águas de İyá Oxum serão sempre abundantes. A poesia Orisá Didé faz referência ao momento em que, no Candomblé, a divindade das águas se manifesta e o orísá toma posse de seu "cavalo", do corpo da filha Omo-orisá de Oxum. O orí de İyá de Oxum. Assim, menciona a Ialodê, "İyá da humanidade", de mulheres poderosas, odu de Oxum, a İyá espiritual que nutre a vida. "İyá suprema em suas canções, orações, rituais", itan e orikis (OYĚWÙMÍ, 2016, p.45).

\section{Epistemologias negras das Águas İyá Oxum}

\author{
Minha fé é negra \\ e minha alma enegrece a terra \\ no ilá \\ que de minha boca escapa.
}


Sou uma árvore negra de raiz nodosa.

Sou um rio de profundidade limosa e calma.

Sou a seta e seu alcance antes do grito.

E mais o fogo, o sal das águas, a tempestade

e o ferro das armas.

E ainda luto em horas de sol obtuso

nas encruzilhadas

(SOUZA, 2011, p. 33, grifos meus)

É relevante notar, finalmente, que o gerar vida depende da gestão/gestação da força de potência, em Yoruba, Axé. No poema-devoção, Abébé omin é o elemento religioso que alimenta a fé e axé nos orixás e, especial, na Orísá Osun ${ }^{18}$. Nele, cultuamse outras formas de viver em sociedade, distanciadas dos padrões hegemônicos orientados por uma cultura ocidental judaico-cristã.

Por outro lado, situam-se na perspectiva da cosmovisão africana de valores e crenças outras, conforme propõe Eduardo Oliveira (2003). "Encantamento Ancestral!" (MACHADO, 2020, p.35). Nos versos, “o encantamento por nossa ancestralidade africana nos leva a seguirmos numa luta engajada por nosso direito à vida, à existência em sua totalidade" (MACHADO, 2020, p.36). A relação entre ancestralidade e espiritualidade é de corpo inteiro.

Não obstante, no poema Abebé Omin, o verbo dançar simboliza ação dos versos feitos em transe. Imortalizam o momento da chegada do orísá e o transe da filha de Oxum que desce no corpo fictício da voz poética: "prepara meu corpo para ser sua morada" e entrega "dourada e rubra minha cabeça a teus pés". Movimento de entrega total à energia ancestral: "[...] para que aqui caminhe, habite, deite e viva, agora e sempre" (SOUZA, 2011, p. 35).

Dança e movimento que se faz também com o leque ritual dourado nas mãos. A dança de Osun lembra "o comportamento de uma mulher vaidosa e sedutora que vai ao rio se banhar, enfeita-se com colares, agita os braços para fazer tilintar seus braceletes, abana-se graciosamente e contempla-se com satisfação" em um abébé (VERGER, 1997, p. 70). Com seus encantos, Oxum é capaz de gerar a vida ou secar tudo, da terra ao ventre. Ela é a grande feiticeira. Ser feiticeira também embute uma relação de poder que desperta, ao mesmo tempo, prazer e medo, pois confunde, seduz e encanta os homens.

\footnotetext{
${ }^{18}$ Deusa do amor, terceira esposa de Xangô, quando vivia na terra, dizem ter sido sua preferida. Muito vaidosa e de temperamento voluptuoso, Oxum usou de todas as artimanhas para prendê-lo, tanto que, por meio de sutilezas, fez a sua rival, Obá, cortar a orelha e cozinhá-la, dizendo-lhe que com isso o agradaria. Sua cor é o amarelo-ouro, e gosta de adornos dourados.
} 
Por outro lado, a ira de Oxum "pode provocar o desencadeamento de contrários a suas qualidades" (CARNEIRO e CURY, 1993, p. 23).

\author{
Oriki para Osun \\ $\mathrm{O}$ rio se cala, \\ mas há quem não saiba \\ que é ele fundo. \\ (SOUZA, 2011, p.73)
}

Dados os poderes místicos que lhe estão associados, os versos de Lívia Natália possuem uma potência de múltiplos afetos que se espraiam no aquoso e liquefeito terreno/território de emoções, sensações e devoções a orísá Oxum. É extraordinária a qualidade de sua linguagem que desce às profundidades abissais dos rios, mares e cachoeiras, traz à superfície a densidade de seus segredos sempre férteis em significados. "Oxum, a İyá primordial, como nos diz o odu Oseetura" (OYĚWÙMÍ, 2016, p.3). Assim, gota a gota... Eu bebo e encanto-me com as palavras-feiticeiras. No movimento de vidas-moléculas, vidas-correntezas, ao mesmo tempo... Neles, o eu lírico é mulher e menina, deusa-rainha, mãe e filha, donas de todos os dengos, segurando o abébé.

Ainda nesse sentido, cabe dizer que Oxum é vida pulsante nas poesias de escritoras negras brasileiras. Poesia negra como ilá (grito) de orixá. Poesia negra feita de abébé nas mãos. Nos versos de Mel Adún e Lívia Natália, os rios de águas doces, negras, lodosas e profundas nunca se calam (SALES, 2018, p. 48). Águas de variadas temperaturas que reviram tudo: passado, presente e futuro numa dimensão de tempo não linear: ora são águas calmas e pacientes... Ora são correntes oceânicas insurgentes, assim como são as mulheres negras que escrevem. Rios que também escondem correntezas perigosas e segredos milenares. "[...] E mais o fogo, o sal das águas, a tempestade" (SOUZA, 2011, p. 33).

Através do espelho-leque, reexistimos belas, sedutoras, vaidosas, bem como produzimos conhecimento de outro lugar. No leque dourado de Oxum que o eu-lírico segura com devoção, podemos exaltar os saberes femininos ancestrais, reverenciar as nossas antepassadas, professar a nossa fé nos orixás e compartilhar as nuances de nossa condição humana e espiritual enquanto mulheres negras. Ademais, aos rituais em devoção a essa divindade das águas doces, intentamos, assim, assentar outras formas de pensamento. 
Por meio de diferentes dinâmicas, são territórios de conhecimento assentados por saberes ancestrais femininos do orixá feminino dos rios, e, particularmente, do rio Oxum em Osogbo. Com Oxum, celebramos as İyá com seus poderes extraordinários. O axé que é transmitido, potencializado, compartilhado e multiplicado através das İyá. Em Oseetura, odu de Oxum, os rios não se calam, "mas há quem não saiba que ele é fundo" (SOUZA, 2011, p. 73).

Como um ilá (grito/choro) de İyá Oxum, as poesias negras femininas de Mel e Lívia se tornam um território simbólico de assentamento do sagrado, dos saberes ancestrais femininos, de itan, orikis e louvações ao Ori (cabeça). Das nossas feitiçarias e “assentamentos de resistência banhados nas/pelas águas İyá Oxum” (SALES, 2020). De águas criando correntezas nas fendas das rochas do pensamento ocidental e racionalizante. De expressão dessa fé negra que sobreviveu ao cativeiro colonial e se ressignificou na diáspora africana.

\section{Referências}

ABIMBOLA, Wande. A concepção iorubá da personalidade humana. Centre National de La Recherche Scientifique, Paris, Tradução Luiz L. Marin: 2011 [1981].

ADÚN, Guellwaar; ADÚN, Mel; RATTS, Alex (Org.). Ogum's toques negros: coletânea poética. Salvador: Ogum's Toques Negros, 2014.

ADÚN, Mel. "Apresentação". In: SOUZA, Lívia Maria Natália de. Água negra. Salvador: EPP Publicações e Publicidade, 2011.

ADÚN, Mel. "Irê”. In: Ogum's Toques Negros. 2012. Disponível em: Acesso em: 19 jun. 2017.

ADÚN, Mel. Cadernos Negros, volume 37: poemas afro-brasileiros/organizadores Esmeralda Ribeiro, Márcio Barbosa. São Paulo: Quilombhoje, 2014.

ADÚN, Mel. "Vou-me embora pra Oshogbo”. In: Ogum's Toques Negros. Organização de Guellwaar Adún, Mel Adún e Alex Ratts. Salvador: Ogum’s Toques Negros, 2014, 146-156.

AKOTIRENE, Carla. "Osun é fundamento epistemológico: um diálogo com Oyèronké Oyèwúmi”. Disponível em https://www.cartacapital.com.br/opiniao/osun-efundamento-epistemologico-um-dialogo-com-oyeronke-oyewumi/acesso em 03 de outubro de 2019.

CARNEIRO, Sueli e CURY, Cristiane Abdon. "O poder feminino no culto aos orixás". In: Mulher Negra. Caderno IV. Edição comemorativa Instituto Geledés da mulher negra, São Paulo: Instituto Geledés, 1993, 19-35. 
EVARISTO, Conceição. "Nos gritos d'Oxum quero entrelaçar minha escrevivência". In: DUARTE, Constância Lima et al. (Org.). Arquivos femininos: literatura, valores, sentidos. Florianópolis: Mulheres, 2014, p. 25-33.

GARUBA, Harry TRADUÇÃO. "Explorações no realismo animista: notas sobre a leitura e a escrita da literatura, cultura e sociedade africana". Nonada: Letras em Revista, vol. 2, núm. 19, octubre, 2012, pp. 235-256.

GILROY, Paul. O Atlântico negro: modernidade de dupla consciência. Trad. Cid Knipel Moreira. São Paulo: Editora 34; Rio de Janeiro: Universidade Candido Mendes, 2001.

GUIMARÃES, Geny Ferreira \& CORDEIRO Hildália Fernandes Cunha. "Campo belo: narrativa insubmissa e insurgente". Anu. Lit., Florianópolis, v. 24, n. 1, p. 131-148, 2019.

HALL, Stuart. Da Diáspora: identidades e mediações culturais. Belo horizonte: Editora UFMG, 2009.

MACHADO, Adilbênia Freire. "Filosofia africana desde saberes ancestrais femininos: bordando perspectivas de descolonização do ser-tão que há em nós". Revista da Associação Brasileira de Pesquisadores/as Negros/as (ABPN), [S.1.], v. 12, n. 31, fev. 2020. ISSN 2177-2770. Disponível em: <http://abpnrevista.org.br/revista/index.php/revistaabpn1/article/view/835>. Acesso em: 17 jun. 2020.

OLIVEIRA, David Eduardo de. Filosofia da ancestralidade: corpo e mito na filosofia da educação brasileira. Curitiba: Editora Gráfica Popular, 2007.

OLIVEIRA, David Eduardo de. Ancestralidade na Encruzilhada. Curitiba: Editora Gráfica Popular, 2007a.

OLIVEIRA, David Eduardo de. Cosmovisão africana no Brasil: elementos para uma filosofia afrodescendente. Curitiba: Editora Gráfica Popular, 2006.

OYĚWÙMÍ, Oyèrónké. "Matripotência: ìyá nos conceitos filosóficos e instituições sociopolíticas [iorubás]" Tradução para uso didático de OYĚWÙMÍ, Oyèrónkẹe. Matripotency: İyá in philosophical concepts and sociopolitical institutions. What Gender is Motherhood? Nova Iorque: Palgrave Macmillan, 2016, capítulo 3, p. 57-92, por Nascimento, Wanderson Flor do. Disponível: https://filosofiaafricana.weebly.com/textos-africanos.html.cAcesso: abril de 2020.

PRANDI, Reginaldo. Mitologia dos Orixás. São Paulo: Companhia das Letras, 2001.

RABELO, Miriam C. M. "Estudar a religião a partir do corpo: algumas questões teórico-metodológicas". Caderno CRH, Salvador, v. 24, n. 61, p. 15-28, Jan./Abr. 2011.

SALES, Cristian Souza de. Da persistência de um esquecimento... a resistência de nossa escrita. http://correionago.com.br/portal/da-persistencia-de-um-esquecimento-aresistencia-de-nossa-escrita/acessado em de abril de 2017. 
SALES, Cristian Souza de. "Lívia Natália: poesia negra feminina de abebé nas mãos". In: AUGUSTO, Jorge (Org.). Contemporaneidades periféricas. Salvador: Segundo Selo, 2018, p. 389-415.

SALES, Cristian Souza de. "Lívia Natália: abébé omin poesia e religiosidade afrobrasileira banhada nas águas de Oxum". Sankofa. Revista de História da África e de Estudos da Diáspora Africana Ano XI, NXXI, setembro/2018.

SALES, Cristian Souza de. Assentamentos de resistência: intelectuais negras do Brasil e Caribe em insurgências epistêmicas (tese de doutorado). Salvador: UFBA, 2020.

SANTOS, Maria Stella de Azevedo. Meu tempo é agora. Assembleia Legislativa do Estado da Bahia, 2010.

SIMAS, Luiz Antonio; RUFINO, Luiz. Fogo no mato: a ciência encantada das macumbas. Rio de Janeiro: Mórula, 2018.

SODRE, Muniz. Pensar Nagô. Rio de Janeiro: Editora Vozes, 2017.

SOUZA, Lívia Maria Natália de. Água Negra e outras águas. Salvador: Caramurê, 2016.

SOUZA, Lívia Maria Natália de. "Literatura adoxada: as formas de escrita poética da negritude na cosmogonia afro-brasileira". Fólio - Revista de Letras Vitória da Conquista v. 10, n. 2 p. 193-204 jul./dez. 2018.

SOUZA, Lívia Maria Natália de. Água negra. Salvador: EPP Publicações e Publicidade, 2011.

SOUZA, Lívia Maria Natália de. Correntezas e outros estudos marinhos. Salvador: Ogum's Toques Negros, 2015.

VERGER, Pierre Fatumbi. Orixás: deuses Iorubás na África e no Novo Mundo. $5^{\mathrm{a}}$ edição. Tradução Maria Aparecida Nóbrega. Salvador: Corrupio, 1997.

VILMA, Ângela. Orelha do livro Água Negra. In: NATÁLIA, Lívia. Água negra. Salvador: EPP Publicações e Publicidade, 2011.

Recebido em: 04/10/2020

Aceito em: 07/10/2020 